\title{
Soil Physical and Biological Conditions as Influenced by Resource Conservation Practices under Cotton Based Soybean Rotation in Vertisols
}

\author{
D. V. Mali*, S. D. Jadhao, V. K. Kharche, P. R. Kadu, P. W. Deshmukh, \\ G. S. Laharia, B. A. Sonune, Nilam Kanase and N. W. Raut \\ Department of Soil Science and Agricultural Chemistry, Dr. Panjabrao Deshmukh Krishi \\ Vidyapeeth Akola- 444104, India \\ *Corresponding author
}

\section{A B S T R A C T}

\section{Keywords \\ Conservation Practices, Soybean, Dehydrogenase activity, Bulk density, $\mathrm{CO}_{2}$ evolution}

\section{Article Info}

\section{Accepted:} 10 September 2020 Available Online: 10 October 2020
The present study was undertaken during 2016-17 at Research farm, Dr. PDKV, Akola. The experiment was laid out in Randomized Block Design with nine treatments replicated three times in Vertisols. The objective of the present experiment was to evaluate the effect of different resource conservation practices on soil physical and biological condition under cotton based soybean rotation in Vertisols. The cotton based soybean rotation was followed since 2011-12. The present experiment was superimposed on soybean during 2016-17. The treatments comprised for soybean crop was recommended dose of fertilizer (RDF) alone and their compensation with organics viz., FYM, phosphocompost, neemcake, bio mulch (farm waste) and green leaf manuring. The results of the present experiment indicated that, the organic carbon was improved with the application of RDF + $\mathrm{PC}$ to soybean and $100 \% \mathrm{~N}(\mathrm{FYM})+$ compensation of $\mathrm{P}$ (phosphocompost) to preceding cotton crop resulted improvement in physical conditions of soils i.e. bulk density (1.33 $\left(\mathrm{Mg} \mathrm{m}^{-3}\right)$, hydraulic conductivity $\left(0.75 \mathrm{~cm} \mathrm{hr}^{-1}\right)$ and AWC $(21.80 \%)$. The biological properties viz; dehydrogenase activity (DHA) $\left(56.8 \mu \mathrm{g} \mathrm{TPF} \mathrm{g}{ }^{-1}\right.$ soil $\left.24 \mathrm{hr}^{-1}\right)$ and $\mathrm{CO}_{2}$ evolution (37.7 $\mathrm{mg} \mathrm{CO}_{2}$ evolved $100^{-1} \mathrm{~g}$ soil) was improved with the application of RDF + PC to soybean and $100 \% \mathrm{~N}$ (FYM) + compensation of P (phosphocompost) to preceding cotton crop. The seed and straw yield of soybean was noticed with RDF to soybean and 25 $\% \mathrm{~N}$ through Neemcake + RDF compensation to preceding cotton crop under cottonsoybean rotation. Thus, it can be inferred that, the management intervention comprising use of RDF along with phosphocompost to soybean and RDF through FYM + remaining P through phosphocompst to cotton crop helps to improve soil physical and biological properties of soil under cotton based soybean rotation in Vertisols.

\section{Introduction}

The enhanced carbon status helps to improve physical and biological properties of soil like bulk density, mean weight diameter, soil microbial biomass carbon, soil microbial biomass nitrogen and other enzymatic activities. The organic carbon is the key parameter in soil which influences all the physical, chemical and biological properties 
of soil. In recent days the content of organic carbon in the soils of semi arid areas is seriously declining.

Soil micro-organisms play a vital role in soil health but are often forgotten in farming systems. There is a growing interest in their beneficial effects, their role as soil health indicators and factors that influence their abundance and diversity. As soil microorganisms decompose the organic matter and assimilate a portion of the nutrients in soils to build their body. The nutrients in soil microbial biomass are mineralized from the dead micro-organisms. Therefore, soil microbial biomass is considered as a source and sinks for nutrients and is an active pool of organic matter in the soil.

The integrated nutrient management envisages the use of chemical fertilizers in conjunction with organic manures, biofertilizers and other locally available nutrient sources for sustaining soil health and productivity. The combined application of organic manures and chemical fertilizers produces higher crop yield than when each is applied alone. This increase in crop productivity may be due to the combined effect of nutrient supply, synergism and improvement in soil physical and biological properties.

Soil physical conditions, no doubt are slow to respond for their improvement but are essential to maintain the health of soils. Soil physical properties have profound influence on nutrient availability which is important attributes of soil quality. Most physical properties of soil are largely influenced by management and the change in physical properties of soil is exhibited only under longterm adoption of management measures. The important physical properties of soil viz., bulk density, hydraulic conductivity, water retention, available water capacity and mean weight diameter are generally considered as soil quality indicators. The basic concept underlying the principles of Integrated Nutrient Management (INM) is the maintenance and possibly improvement of soil fertility for sustaining crop productivity on long-term basis. This may be achieved through combined use of all possible sources of nutrients and their scientific management for optimum growth, yield and quality of different crops and cropping systems.

The favorable effects of FYM on physical properties of soil and also as a source of plant nutrients, which are released on its mineralization and become available to plants is well known. Incorporation of organic manures alone and in combination with inorganic fertilizers resulted into decrease in the $\mathrm{pH}$, bulk density and penetration resistance and increased organic carbon content, porosity, infiltration rate, hydraulic conductivity and water stable aggregates (Chalwade et al., 2006). Managing organic source of plant nutrients with mineral fertilizer and their incorporation into the soil in a cropping system has certain favorable and augmenting effects on soil physical properties for sustainability and high productivity of crop.

In view of the above, the experiment was conducted to assess the effect of Resource Consequence Practices on Soil Physical and Biological Conditions under Cotton based soybean rotation in Vertisols.

\section{Materials and Methods}

The present experiment was carried out during 2016 -17 on cotton based soybean rotation at Research Farm, Department of Soil Science and Agriculture Chemistry, Dr. Panjabrao Deshmukh Krishi Vidyapeeth, Akola. The experiment was laid out in Randomized Block Design with nine 
treatments replicated three times located at between on $22^{\circ} 42^{\prime} \mathrm{N}$ latitude and $77^{\circ} 02^{\prime} \mathrm{E}$ longitude at an altitude of $307.42 \mathrm{~m}$ above MSL and has a subtropical climate. The soil of the experimental site was clayey in nature, Bulk density $1.41 \mathrm{Mg} \mathrm{m}^{-3}$ with $\mathrm{pH} 8.33$ (1:2 soil: water) (Piper, 1966), low in EC (Piper, 1966), low in organic matter content of $5.4 \mathrm{~g}$ $\mathrm{kg}^{-1}$ (Jackson, 1967), low in available $\mathrm{N}$ (Kjeldahl's method) (Subbiah and Asija, 1956), medium in available $P$ (Jackson, 1967) and high in available K (Jackson, 1967) at the start of experiment.

The experiment was laid out in Randomized Block Design with nine treatments replicated three times. The treatments for cotton based soybean rotation are given below (Table 1).

The RDF of soybean was 30:75: $\mathrm{kg} \mathrm{N}, \mathrm{P}$ and $\mathrm{K} \mathrm{ha}^{-1}$. The N, P and $\mathrm{K}$ were applied through fertilizers viz. urea, single super phosphate (SSP) and muriate of potash containing 46, 16.0 and 60 per cent $\mathrm{N}, \mathrm{P}_{2} \mathrm{O}_{5}$ and $\mathrm{K}_{2} \mathrm{O}$, respectively. Soil samples were collected at 0 $15 \mathrm{~cm}$ depth from nine treatment plots of all the three replications before sowing in kharif and after harvest of soybean crop during 2016-17 and used for analysis of physical and biological properties. In brief, bulk density was determined by clod coating technique as described by Blake and Hartge (1986). Hydraulic conductivity of soil was determined by Constant head method by Black (1965).

Available water capacity of soil was determined by Pressure plate membrane apparatus method as per Klute (1986). Dehydrogenase activity determined by Assay method as described by Klein et al., (1971). $\mathrm{CO}_{2}$ evolution was determined by Alkali trap method as described by Anderson (1982).

The plant biomass dry matter of each net plot were threshed, cleaned and weighed. Net plot yield and yield per hectare was calculated separately. The data on different parameters were tabulated and analyzed statistically by the methods described by Panse and Sukhatme (1971).

\section{Results and Discussion}

\section{Soil physical properties}

Bulk density is of greater significance in governing the physical condition of soils, generally soils having low and high bulk densities exhibit favorable and poor physical conditions, respectively.

The effect of different resource conservation practices on bulk density of soil was found to be significant. Numerically lower values of bulk density $\left(1.33 \mathrm{Mg} \mathrm{m}^{-3}\right)$ were recorded in treatment receiving RDF through FYM + remaining $\mathrm{P}$ through phosphocompost $(100 \%$ $\mathrm{N}$ through FYM + compensation of $\mathrm{P}$ through phosphocompost to previous cotton) and was found beneficial in improving soil physical condition.

Lowering the bulk density in organic manure applied may be due to higher organic matter, more pore space and good soil aggregation. Mosavi et al., (2010) showed that the application of green manure effects was significantly improved aggregate stability, soil bulk density and available water capacity (AWC). Sharma et al., (2007) observed that the highest bulk density in the control and it decreased modestly with increasing level of NPK from 50 to $150 \%$ of the recommended dose.

Bulk density in $100 \%$ NPK + FYM was significantly lower than all other treatments. Selvi et al., (2003) revealed that the application of FYM @ $10 \mathrm{t} \mathrm{ha}^{-1}$ along with $100 \%$ NPK recorded significantly lower bulk density. 
Table.1 Treatment details under cotton based soybean rotation

\begin{tabular}{|c|c|c|}
\hline \multirow[t]{2}{*}{ Tr. } & \multicolumn{2}{|l|}{ Rotation } \\
\hline & Cotton & Soybean \\
\hline $\mathrm{T}_{1}$ & $100 \% \operatorname{RDF}\left(50: 25: 00 \mathrm{~kg} \mathrm{NPK} \mathrm{ha}^{-1}\right)$ & $\mathrm{RDF}$ \\
\hline $\mathrm{T}_{2}$ & Sesbania aculeta $25 \% \mathrm{~N}+$ compensation of RDF & $\mathrm{RDF}$ \\
\hline $\mathrm{T}_{3}$ & $\begin{array}{l}\text { Cotton stalk } 25 \% \mathrm{~N} \text { composted with trichoderma viride }+ \\
\text { compensation of RDF }\end{array}$ & RDF \\
\hline $\mathrm{T}_{4}$ & Wheat straw $25 \% \mathrm{~N}+$ compensation of RDF & RDF \\
\hline $\mathrm{T}_{5}$ & Bio mulch (farm waste) $25 \% \mathrm{~N}+$ compensation of RDF & RDF \\
\hline $\mathrm{T}_{6}$ & $\begin{array}{l}\text { Conc. organics (Neemcake) } 25 \% \mathrm{~N}+\text { compensation of } \\
\text { RDF }\end{array}$ & RDF \\
\hline $\mathrm{T}_{7}$ & $\begin{array}{l}100 \% \mathrm{~N} \text { through FYM+ compensation of P through } \\
\text { phosphocompost }\end{array}$ & $\begin{array}{l}\text { RDF through FYM + } \\
\text { remaining P through } \\
\text { phosphocompost }\end{array}$ \\
\hline $\mathrm{T}_{8}$ & $\begin{array}{l}50 \% \mathrm{~N} \text { through } \mathrm{FYM}+\text { compensation of } \mathrm{P} \text { through } \\
\text { phosphocompost \& remaining } \mathrm{N} \text { through urea }\end{array}$ & $\begin{array}{l}\text { RDF through FYM + } \\
\text { remaining P through } \\
\text { phospho- compost }\end{array}$ \\
\hline T9 & $\begin{array}{l}\text { Leucaena loppings } 50 \% \mathrm{~N}+\text { compensation of } \mathrm{P} \text { through } \\
\text { phosphocompost \& remaining } \mathrm{N} \text { through urea }\end{array}$ & $\begin{array}{l}\text { RDF through FYM + } \\
\text { remaining P through } \\
\text { phospho compost }\end{array}$ \\
\hline
\end{tabular}

Table.2 Effect of different resource conservation practices on physical properties of soil after harvest of soybean

\begin{tabular}{|c|c|c|c|c|}
\hline \multirow[t]{2}{*}{ Tr. } & \multicolumn{2}{|l|}{ Treatment details } & \multirow{2}{*}{$\frac{\text { BD }}{\left(\mathbf{M g ~ m}^{-3}\right)}$} & \multirow{2}{*}{$\begin{array}{l}\text { Hydraulic } \\
\text { conductivity } \\
\left(\mathrm{cm} \mathrm{hr}^{-1}\right)\end{array}$} \\
\hline & Cotton & Soybean & & \\
\hline $\mathbf{T}_{1}$ & RDF & RDF & 1.41 & 0.65 \\
\hline $\mathbf{T}_{2}$ & $\begin{array}{l}25 \% \mathrm{~N} \text { (Dhaincha loppings) + RDF } \\
\text { compensation }\end{array}$ & RDF & 1.38 & 0.74 \\
\hline $\mathbf{T}_{3}$ & $\begin{array}{l}25 \% \mathrm{~N} \text { (Cotton stalk) composted + RDF } \\
\text { compensation }\end{array}$ & RDF & 1.40 & 0.67 \\
\hline $\mathbf{T}_{4}$ & $25 \% \mathrm{~N}$ (Wheat straw) + RDF compensation & RDF & 1.36 & 0.66 \\
\hline $\mathbf{T}_{5}$ & $25 \% \mathrm{~N}$ (Bio mulch)+ RDF compensation & RDF & 1.39 & 0.69 \\
\hline$T_{6}$ & $25 \% \mathrm{~N}$ (Neemcake) + RDF compensation & RDF & 1.39 & 0.68 \\
\hline $\mathbf{T}_{7}$ & $\begin{array}{l}100 \% \mathrm{~N}(\mathrm{FYM})+\text { compensation of } \mathrm{P} \\
\text { (phosphocompost) }\end{array}$ & $\mathrm{RDF}+\mathrm{PC}$ & 1.33 & 0.75 \\
\hline $\mathbf{T}_{8}$ & $\begin{array}{l}50 \% \mathrm{~N}(\mathrm{FYM})+\mathrm{P} \text { compensation } \\
\text { (phosphocompost) }+\mathrm{N} \text { compensation (Urea) }\end{array}$ & $\mathrm{RDF}+\mathrm{PC}$ & 1.35 & 0.72 \\
\hline \multirow[t]{4}{*}{$\mathbf{T}_{9}$} & $\begin{array}{l}50 \% \mathrm{~N} \text { (Leucaena loppings) + P compensation } \\
\text { (phosphocompost)+N compensation (Urea) }\end{array}$ & $\mathrm{RDF}+\mathrm{PC}$ & 1.36 & 0.71 \\
\hline & \multicolumn{2}{|l|}{$\mathrm{SE}(\mathrm{m}) \pm$} & 0.02 & 0.02 \\
\hline & \multicolumn{2}{|l|}{$\mathrm{CD}$ at $5 \%$} & 0.05 & 0.06 \\
\hline & \multicolumn{2}{|l|}{ Initial value } & 1.41 & \\
\hline
\end{tabular}


Table.3 Effect of different resource conservation practices on physical properties of soil after harvest of soybean

\begin{tabular}{|c|c|c|c|c|c|}
\hline \multirow[t]{2}{*}{ Tr. } & \multicolumn{2}{|l|}{ Treatment details } & \multirow{2}{*}{$\begin{array}{c}33 \\
\mathbf{k P a}\end{array}$} & \multirow{2}{*}{$\begin{array}{l}1500 \\
\mathrm{kPa}\end{array}$} & \multirow{2}{*}{$\begin{array}{c}\text { AWC } \\
(\%)\end{array}$} \\
\hline & Cotton & Soybean & & & \\
\hline $\mathbf{T}_{1}$ & RDF & RDF & 39.52 & 19.87 & 19.65 \\
\hline $\mathbf{T}_{2}$ & $25 \% \mathrm{~N}$ (Dhaincha loppings) + RDF compensation & RDF & 41.49 & 20.29 & 21.20 \\
\hline $\mathbf{T}_{\mathbf{3}}$ & $\begin{array}{l}25 \% \mathrm{~N} \text { (Cotton stalk) composted }+\mathrm{RDF} \\
\text { compensation }\end{array}$ & $\mathrm{RDF}$ & 40.29 & 19.55 & 20.74 \\
\hline $\mathbf{T}_{4}$ & $25 \% \mathrm{~N}$ (Wheat straw) + RDF compensation & RDF & 40.72 & 19.86 & 20.86 \\
\hline $\mathbf{T}_{5}$ & $25 \% \mathrm{~N}$ (Bio mulch)+ RDF compensation & RDF & 39.38 & 19.27 & 20.11 \\
\hline $\mathbf{T}_{6}$ & $25 \% \mathrm{~N}$ (Neemcake) + RDF compensation & RDF & 40.26 & 19.48 & 20.78 \\
\hline $\mathbf{T}_{7}$ & $\begin{array}{l}100 \% \\
\text { (phosphocompost) }\end{array}$ & $\mathrm{RDF}+\mathrm{PC}$ & 44.15 & 22.35 & 21.80 \\
\hline $\mathbf{T}_{8}$ & $\begin{array}{l}50 \% \mathrm{~N}(\mathrm{FYM})+\mathrm{P} \text { compensation }(\mathrm{PC})+\mathrm{N} \\
\text { compensation (Urea) }\end{array}$ & $\mathrm{RDF}+\mathrm{PC}$ & 41.62 & 20.43 & 21.22 \\
\hline \multirow[t]{3}{*}{$\mathbf{T}_{9}$} & $\begin{array}{l}50 \% \mathrm{~N} \text { (Leucaena loppings) + } \mathrm{P} \text { compensation }(\mathrm{PC})+ \\
\mathrm{N} \text { compensation (Urea) }\end{array}$ & $\mathrm{RDF}+\mathrm{PC}$ & 41.60 & 20.20 & 21.40 \\
\hline & \multicolumn{2}{|l|}{$\mathrm{SE}(\mathrm{m}) \pm$} & 0.45 & 0.56 & 0.40 \\
\hline & \multicolumn{2}{|l|}{$\mathrm{CD}$ at $5 \%$} & 1.34 & 1.68 & 1.21 \\
\hline
\end{tabular}

Table.4 Effect of different resource conservation practices on biological properties of soil

\begin{tabular}{|c|c|c|c|c|}
\hline \multirow[t]{2}{*}{ Tr. } & \multicolumn{2}{|l|}{ Treatment details } & \multirow{2}{*}{$\begin{array}{c}\text { DHA } \\
\left(\mu \mathrm{g} \text { TPF } \mathrm{g}^{-1}\right. \\
\left.\text { soil } 24 \mathrm{hr}^{-1}\right)\end{array}$} & \multirow{2}{*}{$\begin{array}{l}\mathrm{CO}_{2} \text { evolution } \\
\text { (mg CO} \mathrm{CO}_{2} \text { evolved } \\
\left.\mathbf{1 0 0}^{-1} \text { g soil }\right)\end{array}$} \\
\hline & Cotton & Soybean & & \\
\hline $\mathbf{T}_{1}$ & RDF & RDF & 36.98 & 22.08 \\
\hline $\mathbf{T}_{2}$ & $\begin{array}{l}25 \% \mathrm{~N} \text { (Dhaincha loppings) + RDF } \\
\text { compensation }\end{array}$ & RDF & 49.94 & 31.42 \\
\hline $\mathbf{T}_{3}$ & $\begin{array}{l}25 \% \mathrm{~N} \text { (Cotton stalk) composted + RDF } \\
\text { compensation }\end{array}$ & RDF & 39.85 & 27.94 \\
\hline $\mathbf{T}_{4}$ & $\begin{array}{l}25 \% \mathrm{~N} \text { (Wheat straw) + RDF } \\
\text { compensation }\end{array}$ & RDF & 38.88 & 25.57 \\
\hline $\mathbf{T}_{5}$ & $25 \% \mathrm{~N}$ (Bio mulch)+ RDF compensation & RDF & 35.96 & 28.91 \\
\hline$T_{6}$ & $25 \% \mathrm{~N}$ (Neemcake) + RDF compensation & RDF & 40.78 & 22.83 \\
\hline $\mathbf{T}_{7}$ & $\begin{array}{l}100 \% \mathrm{~N} \text { (FYM) + compensation of } \mathrm{P} \\
\text { (phosphocompost) }\end{array}$ & $\mathrm{RDF}+\mathrm{PC}$ & 56.80 & 37.67 \\
\hline $\mathbf{T}_{8}$ & $\begin{array}{l}50 \% \mathrm{~N}(\mathrm{FYM})+\mathrm{P} \text { compensation } \\
\text { (phosphocompost) + N compensation } \\
\text { (Urea) }\end{array}$ & $\mathrm{RDF}+\mathrm{PC}$ & 52.99 & 33.39 \\
\hline \multirow[t]{3}{*}{$\mathbf{T}_{9}$} & $\begin{array}{l}50 \% \mathrm{~N} \text { (Leucaena loppings) }+\mathrm{P} \\
\text { compensation (phosphocompost) }+\mathrm{N} \\
\text { compensation (Urea) }\end{array}$ & $\mathrm{RDF}+\mathrm{PC}$ & 46.61 & 35.10 \\
\hline & \multicolumn{2}{|l|}{$\mathrm{SE}(\mathrm{m}) \pm$} & 3.84 & 3.24 \\
\hline & \multicolumn{2}{|l|}{ CD at $5 \%$} & 11.51 & 9.71 \\
\hline
\end{tabular}


Fig.1 Seed and straw yield as influenced by resource conservation practices

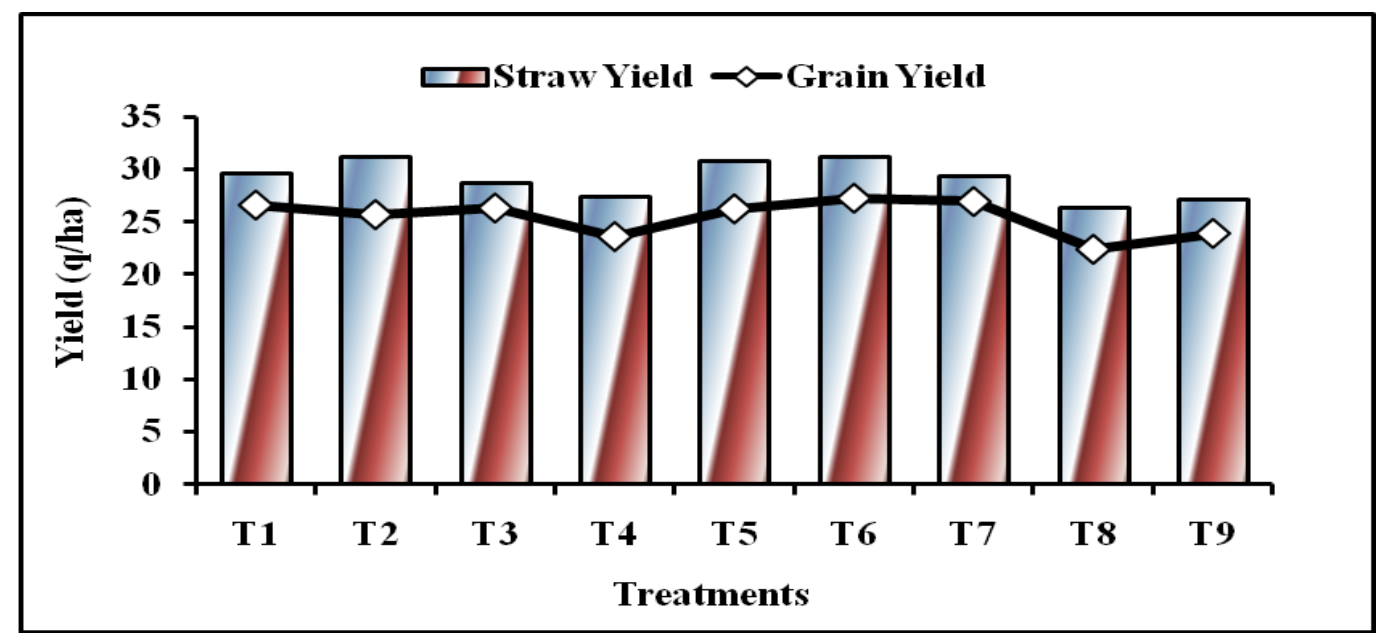

The hydraulic conductivity was higher $(0.75 \mathrm{~cm}$ $\mathrm{hr}^{-1}$ ) with the RDF through FYM + remaining $\mathrm{P}$ through phosphocompost $+(100 \% \mathrm{~N}$ through $\mathrm{FYM}+$ compensation of $\mathrm{P}$ through phosphocompost) followed by RDF + (Cotton stalk $25 \% \mathrm{~N}$ composted with trichoderma viride + compensation of RDF) $\left(0.74 \mathrm{~cm} \mathrm{hr}^{-1}\right)$, RDF through $\mathrm{FYM}+$ remaining $\mathrm{P}$ through phosphocompost+ $(50 \% \mathrm{~N}$ through $\mathrm{FYM}+$ compensation of $\mathrm{P}$ through phosphocompost and remaining $\mathrm{N}$ through urea) $\left(0.72 \mathrm{~cm} \mathrm{hr}^{-1}\right)$ and RDF through FYM + remaining $\mathrm{P}$ through phosphocompost + (Leucaena loppings $50 \% \mathrm{~N}$ + compensation of $\mathrm{P}$ through phosphocompost and remaining $\mathrm{N}$ through urea $\left(0.71 \mathrm{~cm} \mathrm{hr}^{-1}\right)$ showing the significant value. Application of $\mathrm{RDF}+(25 \% \mathrm{~N}$ through wheat straw + compensation of RDF) showing the lower value $(0.65 \mathrm{~cm} / \mathrm{hr})$ of hydraulic conductivity. Similar results were found by Tiwari et al., (2000). They reported that an application of FYM @ 15 $\mathrm{t} \mathrm{ha}^{-1} \mathrm{yr}^{-1}$ along with recommended NPK dose improved all the physical properties of soil. Selvi et al., (2003) reported that the bulk and particle density of the soil have decreased as compared to control. The water holding capacity, pore space, hydraulic conductivity and permeability were found increased considerably.

The water retention at $33 \mathrm{kPa}$ and $1500 \mathrm{kPa}$ varied significantly under study in Table 2 . The significantly highest water retention at $33 \mathrm{kPa}$ (44.15 percent) and at $1500 \mathrm{kPa}$ (22.35 percent) was recorded in with the use of RDF through FYM and remaining $\mathrm{P}$ through phosphocompost (100\% $\mathrm{N}$ through FYM + compensation of $\mathrm{P}$ through phosphocompost to previous cotton). The lower water retention was 39.38 percent at $33 \mathrm{kPa}$ and 19.27 at $1500 \mathrm{kPa}$ was recorded with the use of RDF (25\% N (Bio mulch) + RDF compensation previous cotton crop). It was observed that water retention increased slightly under the FYM and phosphocmpost treatments.

The available water capacity was higher $(21.80$ $\%$ ) with the RDF through FYM + remaining $\mathrm{P}$ through phosphocompost $(100 \% \mathrm{~N}$ through FYM + compensation of $\mathrm{P}$ through phosphocompost to previous cotton) followed by $(21.40 \%)$ RDF through FYM + remaining P through phosphocompost $(50 \% \quad \mathrm{~N}$ through leucaena loppings and $\mathrm{P}$ compensation of $\mathrm{PC}+$ $\mathrm{N}$ compensation through urea to previous crop), (20.74) RDF (25\% N (cotton stalk) + RDF compensation to previous crop cotton), (20.86) RDF (25\% N RDF (wheat straw) + RDF compensation to previous cotton crop), (20.78) RDF (25\% N through Neemcake + RDF Compensation to previous crop cotton). However, these treatments were found at par with each other (Fig. 1). 
Application of recommended dose of fertilizer to both the crop resulted substantial decline in available water capacity $(19.65 \%)$. Similar results were found by Hati et al., (2007) and Mosavi et.al. (2010).

\section{Soil biological properties}

Data presenting as regard to dehydrogenase activity (DHA) influenced by different treatments is presented in Table 3. The significantly highest dehydrogenase activity

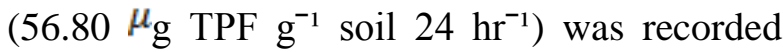
with the application of RDF through FYM + remaining $\mathrm{P}$ through phosphocompost $(100 \% \mathrm{~N}$ through FYM and compensation of $\mathrm{PC}$ to previous crop) followed by RDF through FYM + remaining $\mathrm{P}$ through phosphocompost $(50 \%$ $\mathrm{N}$ through $\mathrm{FYM}+$ compensation of $\mathrm{P}$ through phosphocompost and remaining $\mathrm{N}$ through urea) (52.99 $\mu_{\mathrm{g}}$ TPF $\mathrm{g}^{-1}$ soil $\left.24 \mathrm{hr}^{-1}\right)$. The lowest soil microbial biomass carbon was observed under the application of RDF (Bio mulch (farm waste) $25 \% \mathrm{~N}+$ compensation of RDF) $\left(35.96^{\mu} \mathrm{g}_{\text {TPF }} \mathrm{g}^{-1}\right.$ soil $\left.24 \mathrm{hr}^{-1}\right)$. Similar observations were recorded by Mali et al., (2015).

Significantly highest $\mathrm{CO}_{2}$ evolution $(37.67 \mathrm{Mg}$ $\mathrm{CO}_{2}$ evolved $100^{-1} \mathrm{~g}$ soil) was recorded with the application of RDF through FYM + remaining $\mathrm{P}$ through phosphocompost $(100 \% \mathrm{~N}$ through FYM and compensation of PC to previous crop) followed by RDF through FYM + remaining $\mathrm{P}$ through phosphocompost (Leucaena loppings $50 \% \mathrm{~N}+$ compensation of $\mathrm{P}$ through phosphocompost \& remaining $\mathrm{N}$ through urea) i.e. $\left(35.10 \mathrm{Mg} \mathrm{CO} 2\right.$ evolved $100^{-1} \mathrm{~g}$ soil) showing the at par value. The lowest $\mathrm{CO}_{2}$ evolution was observed under the application of RDF (100\% RDF of previous crop) $(22.08 \mathrm{Mg}$ $\mathrm{CO}_{2}$ evolved $100^{-1} \mathrm{~g}$ soil).

The $\mathrm{CO}_{2}$ evolution was markedly decreased under RDF. Application of organics materials (FYM, phosphocompost) resulted improvement in $\mathrm{CO}_{2}$ evolution as compared to rest of the treatments. Biomass addition through root, leaf, litter and stubble and additional supply of nitrogen through FYM to the microorganisms, might be the reason for improving $\mathrm{CO}_{2}$ evolution. The results are in close agreement with earlier finding of Ingle et al., (2014) and Jadhao et al., (2014) (Table 4).

\section{Yield of soybean}

The seed and straw yield $\mathrm{f}$ soybean was increased significantly with the application of RDF to soybean and $25 \% \mathrm{~N}$ through neemcake + RDF compensation through chemical fertilizers. The application of $\mathrm{RDF}+\mathrm{PC}$ to soybean and $100 \% \mathrm{~N}$ through FYM + compensation of $\mathrm{P}$ through phosphocompost and RDF alone to both soybean and cotton found equally beneficial for getting higher seed and stalk yield of soybean.

It can be concluded that, the application of RDF + phosphocompost to soybean and $100 \% \mathrm{~N}$ through FYM + compensation of $\mathrm{P}$ through phosphocompost to cotton resulted improvement in physical (bulk density, hydraulic conductivity and AWC) and biological properties (dehydrogenase activity $\mathrm{CO}_{2}$ evolution) of soil. The seed and straw yield of soybean was increased with the conjoint use of manures and fertilizers.

\section{References}

Chalwade, P.B., V. K. Kulkarni and M. B. Lakade. 2006. Effect of inorganic and organic fertilization on physical properties of Vertisols. Soils and crops 16(1): 148-152.

Ingle, S. S., S. D. Jadhao, V. K. Kharche, B. A. Sonune and D. V. Mali. 2014. Soil biological properties as influenced by long term manuring and fertilization under sorghum (Sorghum bicolor)-wheat (Triticum aestivum) sequence in Vertisols. Indian Journal of Agricultural Sciences, 84 (4): 452-457.

Jadhao, S. D., A. B. Lokhande, V.K. Kharche, R.D. Chaudhari, D.V. Mali, P. R. Damre. 
2014. Effect of different levels of sulphur and zinc on fertility status and microbial ecology under soybean grown in Vertisols. Journal of Soils and Crops, 24 (1): 57-62.

Piper, C. S. 1966. Soil and plant analysis. Asian Reprint, Hans Publication Bombay, India. Jackson, M. L., 1973. Soil chemical analysis, Prentice Hall of India Pvt. Ltd., New Delhi.

Subbiah, B.V and G. L. Asija, 1956. A rapid procedure for the determination of available nitrogen in soil. Curr. Sci. 25:259-260.

Blake, G. R. and K. H. Hartge, 1986. Bulk density. In: Methods of Soil Analysis, Part-I, Klute, A. (Ed.). American Society of Agronomy Inc. and Soil Science Society of America Inc. Madison, Wisconsin, USA, pp. 371-373.

Black, C. A., D. D. Evans, J. L. White, L. K. Ensingager and F. E. Clark (1965). Method of soil analysis part - II, Amer. Soc. Agron. Inc. No. 9 Madison USA, pp, 770.

Klute, A. 1986. Water retention. Laboratory Method. In A Klute (Ed) Method of soil Analysis Part 1. $2^{\text {nd }}$ ed. Agron. Monograph 9. Madison, Wisconsin. pp 635-662.

Klein, D. A., T. C. Loh and R. L. Goulding. 1971. A rapid procedure to evaluate the dehydrogenase activity of soil low in organic matter. Soil Bio and Biochem. 3: 385-387.

Anderson, J.P.E. (1982) Soil respiration. In A.L.Page, R.H.Miller, and D.R. Keeney (ed.) Method of soil analysis, part 2 . Chemical and microbiological properties, Agronomy Monograph No. 9, ASASSSA Publisher, Madison, Wisconsin, USA, pp. 831-871.
Panse, V. G. and P. V. Sukhatme, 1971. Statistical Methods for Agricultural Workers. ICAR, New Delhi.

Mosavi, S. B., A. A. Jafarzadeh, M. R. Nishabouri, Sh. Ostan, V. Feiziasl and E. Karimi, 2010. The effect of different green manure application in dry land condition on some soil physical properties. Int. J. Agri. Crop. Sci. 4 (17):1233-1239.

Sharma, M. B., S. V. Mishra and R. Singh, 2007. Long term effect of fertilizers and manures on physical and chemical properties of Mollisol. J. Indian Soc. Soil Sci. 55(4): 523-524.

Selvi, D. P., P. Santhy and M. Dhakshinamoorthy, 2003. Efficiency of long term integrated plant nutrient management on important soil properties of an Inceptisol. Madras Agric. J. 90(1012): 656-660.

Tiwari, A., H. R. Nema, B. R. Tembhare and S. K. Sharma, 2000. Soil physical environment in long-term fertilizer experiment on Typic Haplusterts. JNKVV Res. J. 34(1\& 2): 29-33.

Hati, K. M., A. Swarup, A. K. Dwivedi, A. K. Mishra and K. K. Bandyopadhyay, 2007. Changes in soil physical properties and organic carbon status at the topsoil horizon of a Vertisol of central India after 28 years of continuous cropping, fertilization and manuring. Agric. Ecosyst. Environ. 119(2): 127-134.

Mali, D. V., V. K. Kharche, S. D. Jadhao, S. M. Jadhao, B. V. Saoji, P. A. Gite, A.B. Age, 2015. Soil biological health under long term fertilization sorghum - wheat sequence on swell - shrink soil of central Asia. J. Indian Soc. Soil Sci. 63(4): 423428.

\section{How to cite this article:}

Mali, D. V., S. D. Jadhao, V. K. Kharche, P. R. Kadu, P. W. Deshmukh, G. S. Laharia, B. A. Sonune, Nilam Kanase and Raut, N. W. 2020. Soil Physical and Biological Conditions as Influenced by Resource Conservation Practices under Cotton Based Soybean Rotation in Vertisols Int.J.Curr.Microbiol.App.Sci. 9(10): 929-936. doi: https://doi.org/10.20546/ijcmas.2020.910.111 